\title{
PELATIHAN PEMBUATAN DODOL TEMULAWAK UNTUK PENGGEMUKAN SAPI POTONG DI DESA CENGKONG DAN DESA BRANGKAL KECAMATAN PARENGAN KABUPATEN TUBAN
}

\author{
Retno Sri Wahjuni \\ Prodi Pendidikan Kedokteran Hewan, Fakultas Kedokteran Hewan, Universitas Airlangga \\ Prodi.D3 Paramedik Veteriner, Departemen Kesehatan, Fakultas Vokasi, Universitas Airlangga \\ E-mail: wahjuniretno@yahoo.com
}

Siti Eliana Rochmi

Prodi D3 Paramedik Veteriner, Departemen Kesehatan, Fakultas Vokasi, Universitas Airlangga.

E-mail: eliana.rochmi@vokasi.unair.ac.id

Agung Budianto Achmad

Prodi D3 Paramedik Veteriner, Departemen Kesehatan, Fakultas Vokasi, Universitas Airlangga

E-mail: Ab.achmad@vokasi.unair.ac.id

\begin{abstract}
ABSTRAK
Tujuan pengabdian masyarakat ini adalah mengaplikasikan teknologi pembuatan pakan berupa dodol temulawak sebagai upaya untuk menggemukkan sapi potong di Desa Brangkal dan Desa Cengkong Kecamatan Parengan Kabupaten Tuban. Rendahnya pakan yang diberikan dan banyaknya hasil sampingan pertanian yang belum diolah secara maksimal merupakan masalah utama dari kedua mitra. Solusi permasalahan mitra adalah dengan inovasi dodol temulawak yaitu pakan tambahan pengganti konsentrat yang mempunyai kandungan sumber energi dan protein yang baik. Bahan aditif yang digunakan adalah temulawak. Tanaman temulawak merupakan tanaman yang banyak ditanam oleh masyarakat Indonesia khususnya di wilayah mitra. Bahan pembuatan dodol temulawak menggunakan sumber daya lokal yang belum dimanfaatkan secara optimal oleh masyarakat. Metode yang dilakukan dengan pemberdayaan peternak yang diarahkan pada kegiatan peningkatan daya saing dan partisipasi masyarakat melalui peningkatan kapasitas dan kelembagaan SDM peternak dan kelompok ternak dengan peningkatan pengetahuan dan pelatihan pembuatan dodol temulawak. Hasil pengabdian ini menunjukkan hasil positif terhadap pertambahan berat badan sapi potong, dan meningkatkan sumber daya peternak baik secara pengetahuan maupun ketrampilan.
\end{abstract}

Kata kunci: Pakan sapi potong, Dodol Temulawak, Anthelmentik, Pelatihan, pertambahan berat badan sapi potong.

\begin{abstract}
The aim of Public service is to apply feed-making technology in the form of C. Xanthorrhiza, Roxb dodol as an effort to fattening beef cattle in Brangkal Village and Cengkong Village, Parengan Sub-District, Tuban Regency. The low feed provided and the number of agricultural by-products that have not been optimally treated are the main problems of the partners. The solution for partners problem is the innovation of C. Xanthorrhiza, Roxb dodol which is an additional feed substitute for concentrate which has good energy and protein sources. A lot of C. Xanthorrhiza, Roxb are found in Indonesia. It's material used are based on local by-product that have not been used optimally. The method is done by empowering farmers who are directed to activities to increase competitiveness and community participation through increasing the capacity and institutional human resources of farmers and farmers community by increasing knowledge and training in the manufacture of C. Xanthorrhiza, Roxb dodol. The results of this dedication show positive results on weight gain of beef cattle, and increase the resources of farmers both in terms of knowledge and skills.
\end{abstract}

Keywords: Beef Cattle Feed, C. Xanthorrhiza, Roxb, Anthelmintics, Training, Beef Cattle Weight Gain

\section{PENDAHULUAN}

Peternakan sapi rakyat adalah usaha yang banyak dilakukan masyarakat khususnya daerah pedesaan dan merupakan salah satu sumber utama penyediaan daging sapi nasional. Manajemen usaha yang dilakukan peternak rakyat masih secara tradisional sehingga hasil yang didapatkan belum optimal. Pakan ternak sapi potong yang diberikan 
sebagian besar belum mencukupi kebutuhan ternak karena pakan yang diberikan disesuaikan dengan kemampuan peternak (Priyanto, 2011). Rendahnya kualitas pakan yang diberikan dalam waktu yang relatif lama akan menurunkan produktifitas dan kesehatan ternak sapi potong. Sebagian besar kasus yang terjadi jika pemberian pakan yang tidak tepat adalah banyaknya kasus cacingan yang menyerang ternak sehingga usaha penggemukan sapi potong tidak efektif. Pemberian pakan dimaksudkan agar ternak dapat memenuhi kebutuhan hidupnya sekaligus untuk pertumbuhan dan reproduksi. Pakan ternak ruminansia terdiri dari pakan pokok berupa hijauan dan pakan tambahan berupa konsentrat, vitamin dan mineral (Sitindaon, 2013).

Pakan yang berkualitas adalah pakan yang mengandung zat gizi yang dibutuhkan ternak, mudah diperoleh, terjamin ketersediaannya sepanjang waktu, disukai ternak, harga bahan pakan terjangkau, bahan pakan tidak bersaing dengan kebutuhan manusia, dan tidak mengandung racun atau tidak dipalsukan (Hastuti et al., 2013). Pakan ternak berkualitas tinggi dapat menggunakan produk samping (by-product) pertanian yang diolah secara tepat (Diwyanto,

2008). Sebagian besar peternak rakyat khususnya di pedesaan belum memanfaatkan produk samping pertanian secara optimal dikarenakan terbatasnya pengetahuan dan keterampilan dari SDM. Gambaran masalah dari usaha peternakan sapi potong tersebut dialami oleh peternak Desa Brangkal dan Desa Cengkong Kecamatan Parengan Kabupaten Tuban. Usaha peternakan pada kedua desa tersebut masih menggunakan pemeliharaan secara intensif dengan kebersihan kandang yang belum diperhatikan sehingga kejadian kasus cacingan masih tergolong tinggi. Salah satu faktor tingginya angka kasus cacingan adalah sistem pemeliharaan yang tidak sesuai, kebersihan kandang yang tidak terjaga, pemberian pakan yang masih segar, serta keadaan musim pancaroba (Purwatihningsing dkk., 2016).

Kabupaten Tuban merupakan daerah sub sektor pertanian dan peternakan dengan Luas lahan pertanian 183.994,562 Ha yang terdiri lahan sawah seluas 54.860 .530 Ha dan lahan kering seluas 129.134.031 Ha. Lokasi ini ditanami padi serta palawija seperti jagung, kedelai, kacang tanah. kacang hijau, ubi jalar dan ubi kayu, dengan produksi padi sebesar 559.658 ton dan palawija sebesar 1279.98 ton pada tahun 2013. Kecamatan Parengan saat ini merupakan salah satu daerah produsen padi sebesar 749.05 ton dan palawija sebesar 1246.587 ton (Kabupaten Tuban, 2013). Disamping limbah pertanian, Desa Brangkal dan Desa Cengkong juga mempunyai Tanaman Temu khususnya temulawak yang belum dimanfaatkan secara optimal.

Temulawak mengandung bahan aktif seperti antioksidan dan curcumin (Didin, 2009), sebagai anti cacing (antelmentika) karena mengandung xanthorrhizol (Wahjuni dan Retno, 2006; Pramudita dkk., 2013). Temulawak merupakan bahan baku untuk pembuatan Dodol Temulawak atau Temulawak Mollases Blok.

Temulawak Mollases Blok (TMB) atau Dodol Temulawak adalah pakan tambahan pengganti konsentrat yang mempunyai kandungan sumber energi dan protein yang baik. Tujuan pemberian Dodol Temulawak ini adalah untuk meningkatkan daya cerna pakan berserat kasar tinggi dan membentuk asam amino di dalam rumen. Peningkatan daya cerna pakan adalah dengan cara menstabilkan kondisi keasaman $(\mathrm{pH})$ di dalam rumen. Untuk mendapatkan kondisi $\mathrm{pH}$ di dalam rumen yang stabil, maka dodol temulawak diberikan secara jilatan, agar sapi dapat mengatur sendiri kebutuhannya (Wahjuni dan Bijanti, 2006).

Kegiatan Pengabdian Masyarakat PKM ini adalah untuk penyebarluasan dan alih teknologi pengembangan Inovasi Dodol temulawak sebagai pakan bernilai gizi tinggi berbasis sumberdaya lokal merupakan solusi yang efektif dalam penanganan kasus cacingan pada ternak serta pemenuhan pakan yang berkualitas sehingga dapat meningkatkan efisiensi dalam penggemukan sapi potong yang ditunjukkan dengan pertambahan bobot badan yang optimal. Produk Dodol Temulawak hasil dari PKM ini dan diharapkan dapat menekan biaya pakan sehingga meningkatkan pendapatan peternak khususnya pada wilayah mitra.

\section{METODE YANG DIGUNAKAN}

Sasaran dalam pengabdian masyarakat PKM ini adalah Kelompok Ternak Sapi Potong Di Desa Brangkal dan Desa Cengkong Kecamatan Parengan Kabupaten Tuban. Tim pengmas membantu menyelesaikan permasalahan mitra dengan inovasi Dodol Temulawak untuk mengatasi persediaan pakan secara berkualitas dan penanganan kasus cacingan berbasis bahan lokal. Metode yang dilakukan dengan pemberdayaan peternak yang diarahkan pada kegiatan peningkatan daya saing dan partisipasi masyarakat melalui peningkatan kapasitas dan kelembagaan SDM peternak dan kelompok ternak dengan peningkatan pengetahuan dan pelatihan pembuatan dodol temulawak.

Kegiatan ini dilakukan selama tujuh (7) bulan. Prosedur kerja yang dilakukan adalah Tahap survey wilayah kedua mitra; tahap pembinaan dan pelatihan kepada peternak terkait pembuatan dodol temulawak berbasis bahan lokal dengan temulawak sebagai feed additive. Pembinaan ini juga ditunjang dengan sistem pemeliharaan, dan perkandangan yang baik serta penanganan kesehatan reproduksi ternak. Tahap aplikasi pemberian dodol temulawak yang telah dibuat pada ternak percontohan kedua mitra; dan tahap evaluasi. Evaluasi dilakukan dengan pre- dan post test pada mitra untuk melihat kemampuan serapan materi yang diberikan pada tahap pembinaan serta pengukuran berat badan sapi potong 
pre- dan post pemberian dodol temulawak. Perhitungan berat badan sapi menggunakan rumus Schroorl karena sapi percontohan yang dipakai adalah sapi dewasa (Badriyah, 2014). Pengukuran berat badan sapi dengan rumus Schroorl adalah dengan lingkar dada diukur pada tulang rusuk paling depan persis pada belakang kaki depan kemudian dimasukkan ke dalam rumus (Direkrorat Jendral Peternakan, 2010). Rumus Schroorl (Direkrorat Jendral Peternakan, 2010) :

$$
\text { Berat badan }(\mathrm{kg})=\frac{(\mathrm{LD}+22)^{2}}{100}
$$

Keterangan:

LD: lingkar dada (cm)

\section{HASIL DAN PEMBAHASAN}

Pakan yang dibutuhkan oleh ternak adalah hijauan dan konsentrat. Konsentrat digunakan untuk memperbaiki kandungan nutrisi serta sebagai stimulan dan subtrat penopang proses fermentasi. Konsentrat yang biasa digunakan meliputi dedak, bekatul, onggok dan ampas sagu. Onggok bisa ditambahkan sebanyak 2,5\% dari berat hijauan. Sedangkan dedak halus sebanyak 5\% dan jika menggunakan ampas sagu diperlukan $7 \%$ dari berat hijauan.

Konsentrat dapat digantikan dengan dodol temulawak yang mempunyai sumber energi dan protein yang baik. Ternak yang diberi dodol temulawak (Tabel 1) menunjukkan pertambahan berat badan dengan rata-rata $1 \mathrm{~kg} /$ ekor/hari. Hal ini menunjukkan peningkatan Jika dibandingkan sebelum diberikan dodol temulawak (pertambahan berat badan antara 0,3-0,4 kg/ekor/hari). Peningkatan daya cerna pakan dodol temulawak ini adalah dengan cara menstabilkan $\mathrm{pH}$ rumen sehingga energi yang diperlukan dalam proses mencerna menjadi berkurang.

Pada Tabel 1 menunjukkan bahwa terdapat variasi pertambahan bobot badan ternak. Terjadinya perbedaan kemungkinan disebabkan compensatory growth, Ternak yang terbiasa mengonsumsi pakan dengan kualitas nutrisi yang rendah dan bobot awal yang rendah bila diberi pakan dengan kualitas baik akan cenderung mengalami pertambahan berat badan dengan cepat untuk mencapai bobot maksimum sesuai dengan kemampuan genetiknya (Gustiani dan Permadi, 2015).

Pertambahan harian berat badan sapi potong Pada Tabel 1 menunjukkan angka maksimal (1 kg/ekor/hari) hal ini disebabkan oleh pemanfaatan energi ternak dipengaruhi oleh kualitas pakan yang dikonsumsi, termasuk imbangan protein kasar (PK) dan Total Digestible Nutrients (TDN) atau energi. Rasio protein-energi yang sinkron akan menunjukkan efisiensi fermentasi di dalam rumen yang optimal, dalam hal ini energi pakan yang dimanfaatkan untuk proses tersebut akan optimal (Nugroho dkk., 2017).

Bahan aditif pembuatan dodol temulawak termasuk dalam kategori stimulan. Bahan stimulan adalah bahan pakan sumber karbohidrat seperti molasses. Selain itu molases bisa ditambahkan untuk meningkatkan kandungan protein yang berbahan baku jagung. Molasses juga dikenal dengan penambah palatabilitas ternak sapi potong.

Serbuk temulawak yang diberikan sejumlah 3\% dari total bahan. Temulawak mengandung kurkuminoid (3,16\%) dan minyak atsiri $(15,5 \%)$ per $100 \mathrm{~g}$ bahan kering akan memperbaiki keseimbangan mikroba rumen sehingga dapat meningkatkan efisiensi metabolisme dan absorbsi nutrisi. Kurkuminoid dan minyak atsiri bersifat seperti hormon oxytosin yang dapat menurunkan risiko stress pada ternak sehingga penggemukan sapi potong lebih optimal dan efisien (Sulistyowati dkk., 2010). Bahan aktif xanthorrhizol dari

Tabel 1. Pengaruh pemberian dodol temulawak terhadap rataan bobot badan dan pertambahan bobot badan harian (pbbh) ternak sapi potong.

\begin{tabular}{cccccc}
\hline No. Nama Ternak & $\begin{array}{c}\text { Bobot Awal (pre } \\
\text { pemberian Dodol } \\
\text { Temulawak) }\end{array}$ & $\begin{array}{c}\text { Bobot Akhir (post } \\
\text { pemberian Dodol } \\
\text { Temulawak) }\end{array}$ & $\begin{array}{c}\text { Pertambahan BB } \\
\text { (kg/ekor) selama 30 } \\
\text { hari }\end{array}$ & $\begin{array}{c}\text { Rataan } \\
\text { Pertambahan bobot } \\
\text { badan harian (kg/ } \\
\text { ekor/hari) }\end{array}$ \\
\hline 1 & Brangkal 1 & 338,56 & 380,25 & 41,69 & 1,39 \\
2 & Brangkal 2 & 361 & 376,36 & 15,36 & 0,51 \\
3 & Brangkal 3 & 331,24 & 353,44 & 22,2 & 0,74 \\
4 & Brangkal 4 & 278,89 & 306,25 & 27,36 & 0,91 \\
5 & Cengkong 1 & 533,61 & 552,25 & 18,64 & 0,62 \\
6 & Cengkong 2 & 429,25 & 475,24 & 54,99 & 1,83 \\
\hline
\end{tabular}

Rata- rata pertambahan berat badan kg/ekor/hari 
temulawak berfungsi sebagai anti cacing (antelmentika) sehingga dapat digunakan untuk obat cacing, penggunaan temulawak pada ternak sapi relatif aman karena tidak berpengaruh terhadap fungsi hati dan ginjal (Wahjuni dan Retno, 2006; Pramudita dkk., 2013).

\section{KESIMPULAN}

Pembuatan dodol temulawak dapat memberi hasil yang positif dalam pertambahan berat badan sapi potong yang optimal sebesar $1 \mathrm{~kg} / \mathrm{ekor} /$ hari dan dapat digunakan sebagai pencegahan dan pengobatan cacingan pada sapi potong. Pembuatan dodol temulawak dapat diaplikasikan oleh peserta pengabdian dengan menggunakan bahan lokal dan berharga murah.

\section{DAFTAR PUSTAKA}

Badriyah, N. 2014. Kesesuaian Rumus Schoorl Terhadap Bobot Badan Sapi Peranakan Ongole (PO). J. Eksakta. 2(2) : 99-104.

Didin S.T Asripin. 2009. Pengaruh Pemberian Ransum Berimbuhan Temulawak, Zn Proteinat dan Cu Proteinat Terhadap Penurunan Status Mastitis Subklinis Pada Sapi Perah Fries Holland. Seminar Nasional Teknologi Peternakan dan Veteriner.

Direktorat Jendral Peternakan. 2010. Petunjuk Praktek Pengukuran Sapi Potong. Departemen Pertanian Republik Indonesia.

Diwyanto, K. 2008. Pemanfaatan Sumber Daya Lokal Dan Inovasi Teknologi Dalam Mendukung Pengembangan Sapi Potong Di Indonesia. Pengembangan Inovasi Pertanian. 1(3):173-188.

Gustiani, E. dan K. Permadi. 2015. Kajian Pengaruh Pemberian Pakan Lengkap Berbahan Baku Fermentasi Tongkol Jagung Terhadap Produktivitas Ternak Sapi PO Di Kabupaten Majalengka. J. Peternakan 17 (1) : 12-18.
Hastuti, D., A. Shofia Nur, dan M. Baginda Iskandar. 2011 Pengaruh Perlakuan Teknologi Amofer (Amoniasi Fermentasi) Pada Limbah Tongkol Jagung Sebagai Alternatif Pakan Berkualitas Ternak Ruminansia. J. Ilmu Pertanian, 7 (1) : 55-65

Kabupaten Tuban. 2013. Potensi dan Produk Unggulan Jawa Timur.

Nugroho, D., A. Purnomoadi, dan E. Riyanto. 2017. Pengaruh Imbangan Protein Kasar dan Total Digestible Nutrents Pada Pakan Yang Berbeda Terhadap Pemanfaatan Energi Pakan Pada Domba Lokal. Sanins Peternakan, 11(2):63-69.

Pramudita, F.E., E. Trisunuwati, dan R. Indrati.2013. Pengaruh Pemberian Serbuk Ekstrak Temu Hitam (Curcuma aeruginosa ) dan Temu Lawak (Curcuma xanthorrhiza) sebagai Antelmentika Heterakis gallinarum pada Ayam Petelur. Universitas Brawijaya, Hal.1-12

Priyanto, D. 2011. Strategi Pengembangan Usaha Ternak Sapi Potong Dalam Mendukung Program Swasembada Daging Sapi dan Kerbau Tahun 2014. Jurnal Litbang Pertanian, 30(3): 108-116

Purwatihningsing, E. Susanto, dan M. Qomaruddin. 2016. Perbandingan Prevalensi dan Infeksi Parasit Nematoda pada Sapi Potong Antara Model Kandang Berlantai Beton dengan Berlantai Tanah Di Kecamatan Palang Kabupaten Tuban Tahun 2016. Fakultas Peternakan Universitas Islam Lamongan. Journal.unisla.ac.id [Diakses tanggal 26 September 2018]

Sitindaon, S.H. 2013. Inventarisasi Potensi Bahan Pakan Ternak Ruminansia Di Provinsi Riau. J. Peternakan, $10(1): 18-23$.

Sulistowati, E., I. Badarina, dan U. Santoso. 2010. Suplementasi Level Temulawak (Curcuma xanthorrhiza, Roxb) yang Berbeda dalam Konsentrat pada Sapi Frisien Holland Laktasi: Pengaruhnya terhadap Total Digestible Nutrient (TDN) Ransum. J. Sain Peternakan Indonesia, 5(1): 20-26.

Wahjuni, R.S., dan R. Bijanti. 2006. Uji Efek Samping Formula Pakan Komplit terhadap Fungsi Hati dan GinjalPedet Sapi Friesien Holstein. Media Kedokteran Hewan, Vol.22 No.3 Hal. 174-17. 